\title{
Nutritional quality and sensory acceptance of biofortified cassava
}

\section{Qualidade nutricional e aceitação sensorial da mandioca biofortificada}

\author{
Bruna Lago Tagliapietra' (D), Alencar Junior Zanon²* (D), Luana Fernandes Tironi ${ }^{3}$, \\ Nereu Augusto Streck ${ }^{2}$ (1), Neila Silvia Pereira dos Santos Richards ${ }^{1}$ (i) \\ ${ }^{1}$ Universidade Federal de Santa Maria (UFSM), Center of Rural Science, Department of Technology and Food \\ Science, Santa Maria/RS - Brasil \\ ${ }^{2}$ Universidade Federal de Santa Maria (UFSM), Center of Rural Science, Department of Phytotechnics, Santa \\ Maria/RS - Brasil \\ ${ }^{3}$ Empresa de Assistência Técnica e Extensão Rural (Emater/ASCAR-RS), Santa Maria/RS - Brasil
}

${ }^{*}$ Corresponding Author: Alencar Junior Zanon, Federal Universidade Federal de Santa Maria (UFSM), Center of Rural Science, Department of Phytotechnics, Roraima Avenue, Number 1000, CEP 97105-900, Santa Maria/RS Brasil, e-mail: alencarzanon@hotmail.com

Cite as: Tagliapietra, B. L., Zanon, A. J., Tironi, L. F., Streck, N. A., \& Richards, N. S. P. S. (2021). Nutritional quality and sensory acceptance of biofortified cassava. Brazilian Journal of Food Technology, 24, e2020247. https://doi.org/10.1590/1981-6723.24720

\begin{abstract}
It is estimated that the global number of people affected by micronutrient deficiency, known worldwide as hidden hunger, is over two billion and also considered a public health problem. Therefore, this study aimed to evaluate biofortified cassava cultivars in relation to their physical-chemical composition, total carotenoids and to verify their sensory acceptance by schoolchildren. The study was conducted in Santa Maria, in the state of Rio Grande do Sul (RS), Brazil, with four cassava cultivars, two biofortified with yellow pulp (BRS 399 and BRS 396); two non-biofortified varieties: one with yellow pulp ("Gema de ovo") and another with white pulp ("Vassourinha"). After cooking the roots, the nutritional composition (moisture, protein, lipid, ash, and total starch), the total carotenoid content, and the sensory acceptance of the roots by the children at school, in the countryside of Julio de Castilhos and Dilermando de Aguiar, was determined. The contents of moisture, protein, lipids, ash, and starch showed significant variations between the cultivars analyzed. The highest levels of total carotenoids were found in biofortified cultivars $\left(12.85 \mu \mathrm{g} \mathrm{g}^{-1}\right)$.

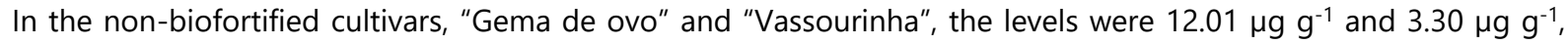
respectively. Sensory acceptance was $78.7 \%$, demonstrating the potential for the insertion of biofortified roots in school meals.
\end{abstract}

Keywords: Agriculture; School feeding; Biofortification; Micronutrients; Vitamin A.

\section{Resumo}

Estima-se que o número global de pessoas afetadas pela deficiência de micronutrientes, também conhecida mundialmente como fome oculta, seja superior a dois bilhões, sendo assim considerada um problema de saúde pública. O objetivo deste estudo foi avaliar cultivares biofortificadas de mandioca quanto a composição físicoquímica e teor de carotenoides totais, além de verificar sua aceitação sensorial por escolares. O estudo foi realizado 
em Santa Maria-RS, Brasil, com quatro cultivares de mandioca, sendo duas variedades biofortificadas com polpa amarela (BRS 399 e BRS 396) e duas variedades não biofortificadas: uma com polpa amarela ("Gema de ovo") e outra com polpa branca ("Vassourinha"). Após o cozimento das raízes, a composição nutricional (umidade, proteína, lipídio, cinzas e amido total), o teor de carotenoides totais e a aceitação sensorial das raízes pelas crianças, nos municípios sul-rio-grandenses de em Júlio de Castilhos e Dilermando de Aguiar, foram determinados. Os teores de umidade, proteína, lipídios, cinzas e amido apresentaram variações significativas entre as cultivares analisadas. Os maiores níveis de carotenoides totais foram encontrados nas cultivares biofortificadas $\left(12,85 \mu \mathrm{g} \mathrm{g}^{-1}\right)$. Nas cultivares não biofortificadas, "Gema de ovo" e "Vassourinha", os níveis foram de 12,01 $\mathrm{mg} \mathrm{g}^{-1}$ e 3,30 $\mu \mathrm{g} \mathrm{g}^{-1}$, respectivamente. A aceitação sensorial foi de 78,7\%, demonstrando potencial para inserção de raízes biofortificadas na alimentação escolar.

Palavras-chave: Agricultura familiar; Alimentação escolar; Biofortificação; Micronutrientes; Vitamina A.

\section{Introduction}

Micronutrient deficiency affects one in four people worldwide, being categorized as a public health problem, also known as "hidden hunger". Hidden hunger occurs when the intake and absorption of vitamins and minerals, such as carotenoids, iron, and zinc, are insufficient to maintain good health and proper human development conditions (Vilas Boas, 2016; Boius \& Birol, 2019).

In Brazil, inadequate levels of vitamin A were observed in 17.4\% of children, with the highest prevalence found in the northeast (19.0\%) and southeast (21.6\%) of the country (Brasil, 2006). The solution to minimizing these micronutrient deficiencies is the consumption of a balanced diet, appropriate to the age, including sufficient quantities of plant and animal nutrients. In the absence of balanced diets, biofortification appears as an effective intervention in feeding the population (Loureiro et al., 2018).

Biofortification is a sustainable, low-cost, and highly efficient process that consists of conventional breeding of plants that are selected until cultivars with higher levels of iron, zinc, and pro-vitamin A are obtained (Carvalho \& Nutti, 2012). These factors mean that biofortification can be widely used in countries with a scarcity of financial and health resources (Ávila et al., 2014). In the long run, biofortification tends to increase the production of nutrient-rich foods and improve food diversity. In the short term, the consumption of biofortified foods can minimize dietary deficiencies, increasing the daily adequacy of micronutrient intake (Bouis \& Saltzman, 2017).

In Brazil, the biofortification of food has been coordinated by the Brazilian Agricultural Research Corporation (Empresa Brasileira de Pesquisa Agropecuária (EMBRAPA), which brings together projects in the area under the name of BioFORT Network. The focus of the work is based on a different aspect when compared to other countries in what concerns the development of biofortification since it involves eight different cultures as following: pumpkin; rice; sweet potato; beans; cowpea; cassava; corn; and wheat. This program by EMBRAPA aims to reduce malnutrition and ensure greater food security, through research focused on the biofortification of basic foods widely produced and present in the population's diet (Reifschneider et al., 2016).

Cassava (Manihot esculenta Crantz) is widespread in the world and in Brazil, where it is predominantly produced by family farming and it is grown in regions where vitamin and mineral deficiency is common, such as in Africa, where the largest world production of cassava is concentrated (FAO, 2015). In Nigeria, the world's largest producer and consumer of cassava, vitamin A deficiency affects $30 \%$ of children under the age of five and $20 \%$ of pregnant women (World Health Organization, 2019). The main evidence of the effectiveness of biofortification in combating vitamin A deficiency comes from studies conducted with orange-fleshed sweet potatoes (Hotz et al., 2012). The absorption of vitamin A from yellow-fleshed cassava was the subject of a study conducted in eastern Kenya with children aged from five to 13, where it showed a significant improvement in the level of vitamin A when compared to the control group (Talsma et al., 2016). However, studies with 
biofortified yellow pulp cassava are still incipient, and few results on the availability of carotenoids in the roots have been found (Carvalho et al., 2012; Bechoff et al., 2017; Fuhrmann et al., 2021).

In Brazil, the law 11.947/2009, which deals with the National School Feeding Program (NSFP), determines that schools and universities must purchase foodstuffs from family farming (Brasil, 2009). By making the purchase of family farming mandatory, supports the producer and provides the means to sell their food. Moreover, it is a possibility for the inclusion of biofortified foods in school meals, ensuring the right to a healthy and adequate diet, as well as contributing to the growth and development of children.

The role of agriculture is essential in nutrition, especially as a primary source of energy and nutrients. Therefore, biofortification has been identified as an alternative in order to provide food consumption with better nutritional quality and a strategy to reduce vitamin A deficiencies, especially in children. Therefore, the objective of the study was to evaluate biofortified cassava cultivars in relation to their physical-chemical composition and carotenoids and to verify their sensory acceptance by school children.

\section{Materials and methods}

\subsection{Sample preparation}

The cultivars used in the present study are shown in Figure 1.

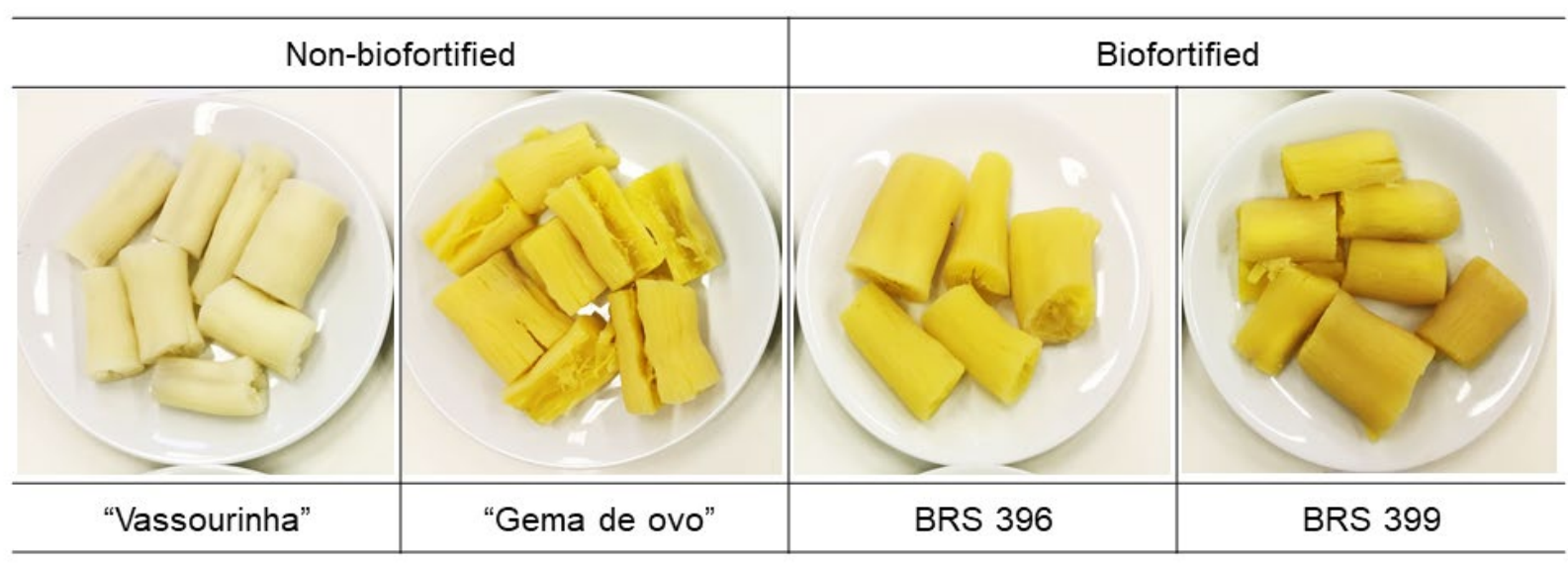

Figure 1. Cassava roots cooked from cultivars.

The biofortified cultivars (BRS 399 and BRS 396) come from the genetic improvement program of the EMBRAPA Cassava and Tropical. "Gema de ovo" is a cultivar of unknown origin, so named by the producers due to the yellow color of the pulp. The commercial cultivar "Vassourinha" (white pulp) for being the most planted and appreciated by consumers in southern Brazil was used as a control (Tironi et al., 2019).

The roots were harvested in the seventh month after planting, a period in which approximately $80 \%$ of commercial crops in the region are harvested (Associação Riograndense de Empreendimentos de Assistência Técnica e Extensão Rural, 2021). For harvesting, three plants from each cultivar were collected at random points. After that, each of them was separated into Marketable Roots (MR), which are those with lengths greater than $10 \mathrm{~cm}$ and diameter greater than $2 \mathrm{~cm}$ (Schons et al., 2009).

After harvesting, the roots were washed under running water, peeled, cut, cleaned with sodium hypochlorite (200 ppm concentration for 15 minutes), had the excess of water drained, vacuum-stored in a plastic bag (polypropylene), and subjected to freezing $\left(-18^{\circ} \mathrm{C}\right)$, for approximately two months. After this period, the roots were cooked for 40 minutes, with a mass ratio of 1:10 (cassava: water) (Talma et al., 2013). 
After cooking, the roots were cut into thin slices of approximately $0.5 \mathrm{~cm}$, dried in an oven at $55^{\circ} \mathrm{C}$, grounded in a Willye knife mill, and stored in plastic bags at $-18{ }^{\circ} \mathrm{C}$ until the analyzes were carried out. Subsequently, the samples were subjected to physical-chemical analysis.

\subsection{Physico-chemical composition}

The nutritional components of the cooked roots evaluated were the contents of moisture, protein, ash, lipid, crude fiber, and total starch. The moisture content of the cooked roots was determined by drying in an oven without air circulation at $105^{\circ} \mathrm{C}$ until a constant weight was obtained (Method 925-10 - Association of Official Analytical Chemists, 2011). The nitrogen content was determined by the micro Kjeldahl method and the conversion to protein was obtained by multiplying the nitrogen content by the conversion factor 6.25 (Method 960-52 - Association of Official Analytical Chemists, 2011). The method used to determine the ash content was incineration in a muffle at $550^{\circ} \mathrm{C}$ until total burning of the organic matter (Method 923-03 - Association of Official Analytical Chemists, 2011). The lipid content was determined by the method of cold extraction by Bligh \& Dyer (1959). The crude fiber was determined using the Ankom ${ }^{\circledR}$ fiber analyzer (200 Fiber Analyzer). Total starch was determined by the Starch Determination Kit (K-RSTAR - (Megazyme International Ltd., Co. Wicklow, Ireland 2011)). All analyzes were performed in triplicates.

\subsection{Extraction and determination of carotenoids}

Carotenoid extraction was performed according to Rodriguez-Amaya (2001). Eight grams of the root samples were weighed in triplicate and $30 \mathrm{~mL}$ of acetone was added. Then, the maceration was carried out and the mixture obtained was vacuum-filtered to a kitassato of $250 \mathrm{~mL}$. The ketone extract was transferred to a separatory funnel, $20 \mathrm{~mL}$ of hexane was added and stirred. For the total removal of acetone and the transference of carotenoids to hexane, two washes were made with distilled water and anhydrous sodium sulfate was added directly to the separation funnel to assist in the separation of the phases. The lower part of the separating funnel (water) was discarded and the extract was transferred to a $25 \mathrm{~mL}$ volumetric flask and swollen with hexane. Hexane was used as "white". The determination of carotenoids in the samples was performed using a UV-Vis spectrophotometer, brand Biospectro, model SP-220 Servilab, according to the analytical methodology for separating and extracting the compounds with organic solvents. For $\beta$-carotene, the absorbance was read at $450 \mathrm{~nm}$ and calculated according to the Rodriguez-Amaya (2001) Equation 1.

Total carotenoid content $\left(u g g^{-1}\right)=\frac{A \times V(m L) \times 10^{4}}{A^{1 \%} \times M(g)}$

where: $\mathrm{A}=$ Absorbance at $450 \mathrm{~nm} ; \mathrm{V}=$ Total volume of the extract in $\mathrm{mL} ; \mathrm{A} 1 \%=$ Absorption coefficient of $\beta$ carotene $=2592 ; \mathrm{M}=$ mass of the sample in $\mathrm{g}$.

The Recommended Daily Intake (RDI) was established based on the proposed by the Technical Regulation on the recommended daily intake of protein, vitamins, and minerals for children aged 7 to 10 years (Brasil, 2005).

All procedures were performed in triplicate and with adequate protection against light, in order to avoid the loss of compounds.

\subsection{Sensory analysis}

Sensory analysis was carried out with 214 untrained evaluators, children from six to 15 years old, of both genders, regularly enrolled in two rural schools, one in the countryside of Júlio de Castilhos and the other in Dilermando de Aguiar, in the state of Rio Grande do Sul, Brazil. 
As the children participating in the sensory analysis were already in the habit of consuming cassava for school meals, and as the objective was to assess the acceptance of biofortified cassava, only BRS 399 and 396 were analyzed. The samples were offered, individually, in the classroom at random at room temperature in disposable plastic plates encoded with random three-digit digits. The tasters were offered a glass of water at room temperature to provide cleaning of the taste buds between sample evaluations. The samples of biofortified cassava roots (BRS 399 and 396) were cooked, served in the classrooms randomly at room temperature in disposable plastic plates, and individually.

The overall acceptance and the color of the biofortified cassava roots were evaluated by the students through the affective acceptance test using the hedonic scale of facial expression, varying from 1 to 5 points, in which axis 1 corresponded to "I detested it" and the axis 5 to "I loved it", where the children pointed the expression corresponding to the opinion about the cassava roots (Ferreira et al., 2000).

The Acceptability Index (AI) was calculated according to the Monteiro equation (1984) (Equation 2), which is considered good acceptance when the AI result was greater than or equal to $85 \%$ (Brasil, 2009).

$A I(\%)=\frac{A \times 100}{B}$

where: $\mathrm{A}=$ average grade obtained for the product; $\mathrm{B}=$ maximum grade attributed to the product.

Only children whose parents signed the Free and Informed Consent Form (ICF), approved by the Research Ethics Committee of the Federal University of Santa Maria, under the number 2,623,612, following CNS Resolution 466/2012, participated in the sensory analysis.

\subsection{Statistical analysis}

The results were analyzed statistically (Analysis of Variance - ANOVA), using the SISVAR $®$ Software and applying the Tukey's test to assess and compare differences between the means $(p<0.05)$. The data obtained for the sensorial analysis were qualitative and submitted to descriptive statistical analyzes.

\section{Results and discussion}

\subsection{Physico-chemical composition}

The analysis of the physical-chemical composition was carried out with the cooked roots since the cassava is a tuberous root of hard pulp when in nature, which needs cooking before consumption to acquire a suitable texture (Alamu et al., 2017). The results of the physical-chemical composition of the roots are shown in Table 1.

Table 1. Physico-chemical compositions of cassava roots of the cultivars "Vassourinha", "Gema de ovo", BRS 399 and BRS 396.

\begin{tabular}{cccccc}
\hline Compositions & "Vassourinha" & “Gema de Ovo" & BRS 399 & BRS 396 & CV (\%) \\
\hline Moisture (\%) & $73.25^{\mathrm{b}}$ & $79.10^{\mathrm{a}}$ & $74.94^{\mathrm{b}}$ & $78.43^{\mathrm{a}}$ & 1.51 \\
\hline Protein (\%)* & $1.19^{\mathrm{a}}$ & $1.13^{\mathrm{a}}$ & $1.26^{\mathrm{a}}$ & $0.68^{\mathrm{b}}$ & 6.90 \\
\hline Ash (\%)* & $0.40^{\mathrm{c}}$ & $0.53^{\mathrm{b}}$ & $0.54^{\mathrm{b}}$ & $0.62^{\mathrm{a}}$ & 5.35 \\
\hline Lipid (\%)* & $0.23^{\mathrm{a}}$ & $0.26^{\mathrm{a}}$ & $0.23^{\mathrm{a}}$ & $0.24^{\mathrm{a}}$ & 8.67 \\
\hline Crude fiber (\%)* & $1.57^{\mathrm{ab}}$ & $1.50^{\mathrm{b}}$ & $1.66^{\mathrm{a}}$ & $1.69^{\mathrm{a}}$ & 3.39 \\
\hline Total Starch (\%)* & $23.22^{\mathrm{a}}$ & $17.59^{\mathrm{b}}$ & $21.36^{\mathrm{a}}$ & $18.32^{\mathrm{b}}$ & 5.72 \\
\hline
\end{tabular}

Same lowercase letters on the line do not differ statistically from each other by the Tukey's test, at the $5 \%$ significance level $(p<0,05)$. $*$ Results expressed by the average of the triplicate on a wet basis. $\mathrm{CV}=$ Coefficient of Variation. 
The cultivars showed low protein content, which is in agreement with other studies carried out on the composition of cassava root (Padonou et al., 2005; Maieves et al., 2012). Protein contents ranged from $0.68 \%$ to $1.26 \%$ (Table 1). Cassava is considered an energetic food source due to its low protein and high carbohydrate content. The highest levels of protein are found in the leaves of the plant, which can vary from $6.6 \%$ to $23.5 \%$ depending on some factors such as harvest and cultivar season (Tagliapietra et al., 2019).

In the cultivars analyzed, the lowest ash content was found in the cultivar "Vassourinha" $(0.40 \%)$, differing significantly ( $p$-value $\leq 0.05$ ) from biofortified cultivars, which presented the highest ash contents (average $0.58 \%$ ) (Table 1). Probably the highest levels of ash in biofortified cultivars are due to the highest levels of $\mathrm{Ca}, \mathrm{P}, \mathrm{Fe}$, and $\mathrm{Mg}$. The lipid content of the cultivars analyzed did not differ statistically ( $p$-valor $>0.05$ ). Cassava is known for having a low lipid content, on average $0.3 \%$ (Maieves et al., 2012). Crude fiber showed a significant difference between samples, ranging from $1.50 \%$ to $1.69 \%$. Some authors claim that the fiber content in cassava roots may increase with the age of the plant, focusing on the center of the product (Lorenzi, 1994; Souza et al., 2010).

Starch is the most important source of carbohydrates in human food, representing $80 \%$ to $90 \%$ of all polysaccharides in the diet (Leonel, 2009). The cultivars differed significantly in relation to the starch content of the roots, varying from $17.59 \%$ to $23.22 \%$. Similar results were found by other authors (Oliveira \& Moraes, 2009; Alcázar-Alay \& Meireles, 2015) who highlighted that the quantity and properties of starch were associated with genetics, which could vary between cultivars.

\subsection{Total carotenoids in biofortified cassava roots}

The results obtained for the analysis of carotenoids from biofortified cassava roots are shown in Table 2 .

Table 2. Carotenoid content $\left(\mu \mathrm{g} \mathrm{g}^{-1}\right)$ in cooked cassava roots.

\begin{tabular}{ccc}
\hline Cultivars & Total Carotenoids $\left(\boldsymbol{\mu g} \mathbf{g}^{-1}\right) *$ & \% RDI \\
\hline "Vassourinha" & $3.30^{\mathrm{b}}$ & 7 \\
\hline "Gema de Ovo" & $12.01^{\mathrm{a}}$ & 28 \\
\hline BRS 399 & $13.14^{\mathrm{a}}$ & 30 \\
\hline BRS 396 & $12.57^{\mathrm{a}}$ & 29 \\
\hline CV (\%) & 7.74 & \\
\hline
\end{tabular}

Same lowercase letters in the column do not differ statistically from each other by the Tukey's test, at the $5 \%$ significance level $(p<0,05)$. CV $=$ Coefficient of Variation. ${ }^{*}$ Results expressed by the average of the triplicate on a wet basis. RDI $=$ Recommended Daily Intake of $\mu$ g per day for children aged seven to 10 years. \% RDI calculated on $100 \mathrm{~g}$ portion of cooked cassava ready for consumption

The carotenoid contents of BRS 399 and BRS 396 (biofortified) were similar to that of the cultivar "Gema de ovo", with no significant difference between the analyzed samples of cultivars with yellow pulp. The possibility of adding nutritional qualities to the cassava roots (biofortification) directed the breeding programs towards the selection of table cassava clones with yellow root coloring since there is a positive correlation between the intensity of the yellow coloring of the roots and their carotenoid levels (Chávez et al., 2005; Lawal et al., 2021), which was found in this study. In addition, biofortified cultivars have high productive potential, have a structure that facilitates crop treatment and harvesting, are more resistant to the main pests and diseases, in addition to having high agronomic and technological value (Silva et al., 2014).

The values of total carotenoids found in biofortified cultivars were much higher than the cultivar "Vassourinha", of white pulp, for which the content of $3.30 \mu \mathrm{g} \mathrm{g}^{-1}$ of total carotenoids was obtained. The total carotenoid content of cassava roots can be considered a good indicator of the $\beta$-carotene content, as studies have revealed that on average $70 \%$ of the carotenoid contents correspond to $\beta$-carotene (Mezette et al., 2009; Carvalho et al. 2012). The metabolic conversion of $\beta$-carotene to vitamin $A$ is chemically possible due 
to its molecular structure, thus, carotenoids can theoretically generate two molecules of vitamin A (Rodriguez-Amaya, 2001).

The results found in this study were similar to those of Carvalho et al. (2012) when analyzing seven yellow pulp cassava cultivars in Cruz das Almas, in the state of Bahia (BA), Brazil, in which the levels of carotenoids ranged from 2.64 to $14.15 \mu \mathrm{g} \mathrm{g} \mathrm{g}^{-1}$ (1668 "Cacau amarelo" and 1456 "Vermelhinha", respectively). Mezette et al. (2009) evaluated thirteen cassava cultivars with potential for insertion in the breeding program and reported levels of carotenoids ranging from 3.30 to $11.08 \mu \mathrm{g} \mathrm{g}^{-1}$. Variations in the amount of root carotenoids can be caused by genetic and environmental factors, such as soil, climate, temperature, season, light, and harvest time (Rodriguez-Amaya, 2001).

Research in Mozambique evaluating sweet potato consumption by children showed that biofortification can improve children's health, due to a significant increase in body stores of vitamin A (Haskell et al., 2004; Low et al., 2007). A study carried out in Zambia with children aging from five to 7 years old showed that, after three months of consumption of biofortified corn, body stores of vitamin A in children who consumed biofortified corn increased significantly compared to children in the control group (Gannon et al., 2014).

For children aging from seven to 10 years old, the RDI of vitamin A is $450 \mu \mathrm{g}$ retinol, according to the Brazilian Health Regulatory Agency (Agência Nacional de Vigilância Sanitária (ANVISA)) in resolution RDC 269, of September 22, 2005 (Brasil, 2005). A 100g-portion of yellow-fleshed cassava can provide around $30 \%$ of the RDI for this infant group (Table 2) and can be an effective alternative to minimize vitamin A deficiencies in low-income populations.

\subsection{Sensory analysis}

Of the 214 survey participants, aged six to 15,114 were males and 97 females, both were school children enrolled in rural schools in the public elementary school in Rio Grande do Sul, Brazil. The results obtained in the hedonic facial scale test of biofortified cassava roots are shown in Figure 2.
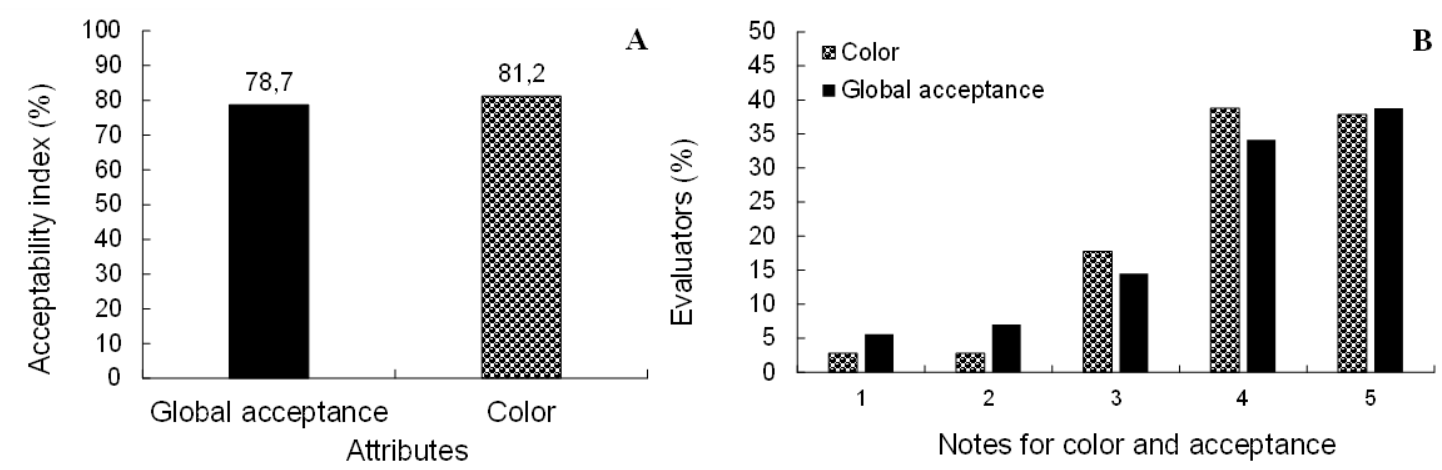

Figure 2. Acceptability index (\%) (A) and distribution of the marks attributed by the evaluators (B) of the biofortified cassava roots, BRS 399 and BRS 396, in relation to the global acceptance and color attributes.

For a product to be considered acceptable, it is necessary to obtain acceptance of at least $85 \%$ (Brasil, 2009). In this study, biofortified cassava roots showed $80 \%$ of acceptance, lower than the minimum recommended for insertion in school meals, requiring a second sensory analysis with a minimum interval of two months. The temperature may have interfered with the acceptance as well as the lower hedonic scale scores can be attributed to the form of consumption, since cassava is often used in school meals along with other foods.

In Figure 1B, it is possible to verify that the evaluators' scores for the same attributes, color, and global acceptance, were mostly classified as "I liked it a lot (4)" and "I loved it (5)". The color and appearance of the roots are important, as these attributes are associated with personal reactions of acceptance, indifference, 
or rejection. The color of the pulp is extremely important since the visual presentation is the first criterion to be analyzed by consumers (Teixeira, 2009). Although the children participating in the research were used to consuming white-fleshed cassava, the results showed that the yellow color of the roots was well accepted by the students.

The biofortification technique presents itself as an alternative to minimize vitamin A deficiencies in lowincome populations. However, it is necessary that biofortified crops are the food base for most of those populations. The results found can contribute to public policies and food biofortification programs, producing knowledge about the composition of the roots and the availability of carotenoids, for the reduction of vitamin A deficiency in affected populations. In addition, the programs might contribute to the development of family farming, being an alternative to add value to cassava, since it is almost entirely produced through family farming.

\section{Conclusion}

The moisture, protein, lipid, ash, and starch contents showed small variations between the cultivars analyzed. The highest levels of carotenoids were found in biofortified cultivars BRS 399 and BRS 396, and also in the cultivar "Gema de ovo". The results of the sensory analysis demonstrated the potential for the insertion of biofortified roots in school meals. Nevertheless, it is necessary to carry out new sensory analyzes in order that the acceptability meets the requirements of the National School Nutrition Program. In addition, cassava has great importance in the social context, and the appreciation and opening of new markets promote the development and appreciation of local family farming since it is a culture predominantly cultivated by small producers.

\section{Acknowledgements}

The authors would like to thank the National Council for Scientific and Technological Development (Conselho Nacional de Desenvolvimento Cientifico e Tecnológico (CNPq)) and the Coordination for the Improvement of Higher Education Personnel (Coordenação de Aperfeiçoamento de Pessoal de Nível Superior (CAPES)), Financial Code 001 for providing scholarships and financial support for this work. The authors would also like to thank the students who are part of the Simanihot Team and helped to conduct the field experiment.

\section{References}

Alamu, E. O., Maziya-Dixon, B., \& Dixon, A. G. (2017). Evaluation of proximate composition and pasting properties of high quality cassava flour (HQCF) from cassava genotypes (Manihot esculenta Crantz) of $\beta$-carotene-enriched roots. LebensmittelWissenschaft + Technologie, 86, 501-506. http://dx.doi.org/10.1016/j.Iwt.2017.08.040

Alcázar-Alay, S. C., \& Meireles, M. A. (2015). Physicochemical properties, modifications and applications of starches from different botanical sources. Food Science and Technology (Campinas), 35(2), 215-236. http://dx.doi.org/10.1590/1678457X.6749

Associação Riograndense de Empreendimentos de Assistência Técnica e Extensão Rural - EMATER/RS - Ascar (2021). Informativo Conjuntural Retrieved in 2021, April 26, from http://www.emater.tche.br/site/info-

agro/informativo_conjuntural.php\#.YliCcLVKjIU

Association of Official Analytical Chemists - AOAC. (2011). Official methods of analysis of the Association of Official Analytical Chemists. (18th ed.). Gaithersburg: AOAC.

Ávila, F. W., Yang, Y., Faquin, V., Ramos, S. J., Guilherme, L. R., Thannhauser, T. W., \& Li, L. (2014). Impact of selenium supply on Se-methylselenocysteine and glucosinolate accumulation in selenium-biofortified Brassica sprouts. Food Chemistry, 165, 578-586. PMid:25038715. http://dx.doi.org/10.1016/j.foodchem.2014.05.134

Bechoff, A., Taleon, V., Carvalho, L. M. J., Carvalho, J. L. V., \& Boy, E. (2017). Micronutrient (provitamin A and iron/zinc) retention in biofortified crops. African Journal of Food, Agriculture, Nutrition and Development, 17(2), 11893-11904. http://dx.doi.org/10.18697/ajfand.78. HarvestPlus04

Bligh, E. G., \& Dyer, W. J. (1959). A rapid method of total lipid extraction and purification. Canadian Journal of Biochemistry and Physiology, 37(8), 911-917. PMid:13671378. http://dx.doi.org/10.1139/o59-099 
Boius, H. E., \& Birol, A. S. E. (2019). Improving nutrition through biofortification. In S. Fan, S. Yosef, \& R. Pandya-Lorch (Eds.), Agriculture for improved nutrition: Seizing the momentum (pp. 47 -57). Washington: IFPRI. http://dx.doi.org/10.1079/9781786399311.0000.

Bouis, H. E., \& Saltzman, A. (2017). Improving nutrition through biofortification: a review of evidence from HarvestPlus, 2003 through 2016. Global Food Security, 12, 49-58. PMid:28580239. http://dx.doi.org/10.1016/j.gfs.2017.01.009

Brasil. (2005). Aprova o "Regulamento Técnico sobre a Ingestão Diária Recomendada (IDR) de proteína, vitaminas e minerais" (Resolução n² 269, de 22 de setembro de 2005). Diário Oficial [da] República Federativa do Brasil, Brasília.

Brasil. (2009). Dispõe sobre o atendimento da alimentação escolar e do Programa Dinheiro Direto na Escola aos alunos da educação básica (Lei no 11.947 de 16 de junho de 2009). Diário Oficial [da] República Federativa do Brasil, Brasília.

Brasil. Ministério da Saúde. (2006). Pesquisa Nacional de Demografia e Saúde da Mulher e da Criança. Brasília: Ministério da Saúde.

Carvalho, J., \& Nutti, M. R. (2012). Biofortificação de produtos agrícolas para nutrição humana. Brasília: Embrapa Agroindústria de Alimentos.

Carvalho, L. M. J., Oliveira, A. R. G., Godoy, R. L. O., Pacheco, S., Nutti, M. R., de Carvalho, J. L. V., Pereira, E. J., \& Fukuda, W. G. (2012). Retention of total carotenoid and ß-carotene in yellow sweet cassava (Manihot esculenta Crantz) after domestic cooking. Food \& Nutrition Research, 56(1), 15788. http://dx.doi.org/10.3402/fnr.v56i0.15788

Chávez, A. L., Sánchez, T., Jaramillo, G., Bedoya, J. M., Echeverry, J., Bolaños, E. A., Ceballos, H., \& Iglesias, C. A. (2005). Variation of quality traits in cassava roots evaluated in landraces and improved clones. Euphytica, 143(1-2), 125-133. http://dx.doi.org/10.1007/s10681-005-3057-2

Food and Agriculture Organization of the United Nations - FAO. (2015). Production crop data. Retrieved in 2019, October 23, from http://faostat3.fao.org/browse/Q/QC/E2014

Ferreira, V. L. P., et al (2000). Análise sensorial: testes discriminativos e afetivos. SBCTA, Campinas, 127p.

Fuhrmann, E., Vieira, E. A., Faleiro, F. G., \& Fialho, J. F. (2021). Caracterização morfológica de clones elite biofortificados de mandioca de mesa com polpa rosada. Brazilian Journal of Animal and Environmental Research, 4(1), 1384-1398. http://dx.doi.org/10.34188/bjaerv4n1-115

Gannon, B., Kaliwile, C., Arscott, S., Schmaelzle, S., Chileshe, J., Kalungwana, N., Mosonda, M., Pixley, K., Masi, C., \& Tanumihardjo, S. A. (2014). Biofortified orange maize is as efficacious as a vitamin A supplement in Zambian children even in the presence of high liver reserves of vitamin A: A community-based, randomized placebo-controlled trial. The American Journal of Clinical Nutrition, 100(6), 1541-1550. PMid:25411289. http://dx.doi.org/10.3945/ajen.114.087379

Haskell, M. J., Jamil, K. M., Hassan, F., Peerson, J. M., Hossain, M. I., Fuchs, G. J., \& Brown, K. H. (2004). Daily consumption of Indian spinach (Basella alba) or sweet potatoes has a positive effect on total-body vitamin A stores in Bangladeshi men. The American Journal of Clinical Nutrition, 80(3), 705-714. PMid:15321812. http://dx.doi.org/10.1093/ajcn/80.3.705

Hotz, C., Loechl, C., Lubowa, A., Tumwine, J. K., Ndeezi, G., Nandutu Masawi, A., Baingana, R., Carriquiry, A., de Brauw, A., Meenakshi, J. V., \& Gilligan, D. O. (2012). Introduction of $\beta$-carotene-rich orange sweet potato in rural Uganda results in increased vitamin A intakes among children and women and improved vitamin A status among children. The Journal of Nutrition, 142(10), 1871-1880. PMid:22875553. http://dx.doi.org/10.3945/jn.111.151829

Lawal, O. M., Talsma, E. F., Bakker, E. J., Fogliano, V., \& Linnemann, A. R. (2021). Novel application of biofortified crops: consumer acceptance of pasta from yellow cassava and leafy vegetables. Journal of the Science of Food and Agriculturae, 101(14):6027-6035. http://dx.doi.org/10.1002/jsfa.11259.

Leonel, M. (2009). Desenvolvimento de produtos funcionais à base de mandioca (pp. 29-38). Botucatu: ERAT/UNESP. Lorenzi, J. O. (1994). Variação na qualidade culinária das raízes de mandioca. Bragantia, 53(2), 237-245. http://dx.doi.org/10.1590/S0006-87051994000200013

Loureiro, M. P., Cunha, L. R., Nastaro, B. T., Pereira, K. Y. S., \& Nepomoceno, M. L. (2018). Biofortificação de alimentos: problema ou solução? Segurança Alimentar e Nutricional, 25(2), 66-84. http://dx.doi.org/10.20396/san.v25i2.8652300

Low, J. W., Arimond, M., Osman, N., Cunguara, B., Zano, F., \& Tschirley, D. (2007). A food-based approach introducing orange fleshed sweet potato increased vitamin $A$ intake and serum retinol concentrations in young children in rural Mozambique. The Journal of Nutrition, 137(5), 1320-1327. PMid:17449599. http://dx.doi.org/10.1093/jn/137.5.1320

Maieves, H. A., Oliveira, D. C. D., Bernardo, C., Müller, C. M. D. O., \& Amante, E. R. (2012). Microscopy and texture of raw and cooked cassava (Manihot Esculenta Crantz) roots. Journal of Texture Studies, 43(2), 164-173. http://dx.doi.org/10.1111/j.17454603.2011.00327.x

Mezette, T. F., Carvalho, C. R. L., Morgano, M. A., Silva, M. G., Parra, E. S. B., Galera, J. M. S. V., \& Valle, T. L. (2009). Seleção de clones-elite de mandioca de mesa visando a características agronómicas, tecnológicas e químicas. Bragantia, 68(3), 601-609. http://dx.doi.org/10.1590/S0006-87052009000300006

Oliveira, M. A., \& Moraes, P. S. B. (2009). Características físico-químicas, cozimento e produtividade de mandioca cultivar IAC 576-70 em diferentes épocas de colheita. Ciência e Agrotecnologia, 33(3), 837-843. http://dx.doi.org/10.1590/S141370542009000300024

Padonou, W., Mestres, C., \& Nago, M. C. (2005). The quality of boiled cassava roots: instrumental characterization and relationship with physicochemical properties and sensorial properties. Food Chemistry, 89(2), 261-270. http://dx.doi.org/10.1016/j.foodchem.2004.02.033 
Reifschneider, F. J. B., Lopes, C. A., \& Ribeiro, C. S. C. (2016). Continuity, focus and impact: A commented historical perspective on Embrapa Vegetables' extended Capsicum breeding program. Horticultura Brasileira, 34(2), 155-160. http://dx.doi.org/10.1590/S0102-053620160000200002

Rodriguez-Amaya, D. B. (2001). A guide to carotenoid analysis in food (64 p.). Washington: OMNI Research.

Schons, A., Streck, N. A., Storck, L., Buriol, G. A., Zanon, A. J., Pinheiro, D. G., \& Kraulich, B. (2009). Arranjos de plantas de mandioca e de milho em cultivo solteiro e consorciado: Crescimento, desenvolvimento e produtividade. Bragantia, 68(1), 155167. http://dx.doi.org/10.1590/S0006-87052009000100017

Silva, K. N., Vieira, E. A., Fialho, J. F., Carvalho, L. J. C. B., \& Silva, M. S. (2014). Potencial agronômico e teor de carotenoides em raízes de reserva de mandioca. Ciência Rural, 44(8), 8. http://dx.doi.org/10.1590/0103-8478cr20130606

Souza, M. J. L., Viana, A. E. S., Matsumoto, S. N., Vasconcelos, R. C., Sediyama, T., \& Morais, O. M. (2010). Características agronômicas da mandioca relacionadas à interação entre irrigação, épocas de colheita. Acta Scientiarum. Agronomy, 32(1), 4553. http://dx.doi.org/10.4025/actasciagron.v32i1.720

Tagliapietra, B. L., Zanon, A. J., Silva, M. N., Alves, A. F., Freitas, C. P. O., Tironi, L. F., Jimenez, M. S. E., Cardoso, P., Santos, A. T. L., Tonel, G. P., Rodrigues, L. B., Richards, N. S. P. S., Streck, N. A. (2019). Mandioca para alimentação humana e animal (104 p.). Santa Maria: Ed. GR.

Talma, S. V., Almeida, S. B., Lima, R. M. P., Vieira, H. D., \& Bebert, P. A. (2013). Tempo de cozimento e textura de raízes de mandioca. Brazilian Journal of Food Technology, 16(2), 133-138. http://dx.doi.org/10.1590/S1981-67232013005000016

Talsma, E., Brouwer, I. D., Verhoef, H., Mbera, G. N., Mwangi, A. M., Demir, A. Y., Maziya-Dixon, B., Boy, E., Zimmermann, M. B., \& Melse-Boonstra, A. (2016). Biofortified yellow cassava and vitamin A status of Kenyan children: A randomized controlled trial. The American Journal of Clinical Nutrition, 103(1), 258-267. PMid:26675768. http://dx.doi.org/10.3945/ajcn.114.100164

Teixeira, L. V. (2009). Análise sensorial na indústria de alimentos. Revista do Instituto de Latícinios Cândido Tostes, 64, $12-21$.

Tironi, L. F., Zanon, A. J., Alves, A. F., Freitas, C. P. O., Santos, A. T. L., Cardoso, P., Tonel, G. P., Rodrigues, L. B.,

Tagliapietra, B. L., Silva, M. N., Streck, N. A.(2019). Ecofisiologi da mandioca visando altas produtividades (136 p.). Santa Maria: Ed. GR.

Vilas Boas, L. G. (2016). Fome oculta e seus liames como a economia, a política e a sociedade. Revista Digital para Estudiantes de Geografía y Ciencias Sociales, 90(7), 207-232.

World Health Organization - WHO. (2019). Micronutrient Initiative (MI). Retrieved in 2019, October 11, from http: www.micronutrient.org/english/View.asp?x=596

Funding: Coordination for the Improvement of Higher Education Personnel (CAPES), Financial Code 001/National Council for Scientific and Technological Development. 